\title{
Doctoral Students' Emotional Exhaustion and Intentions to Leave Academia
}

\author{
Karen H. Hunter \\ University of Alberta, \\ Edmonton, Alberta, Canada
}

Karen.hunter@ualberta.ca

\author{
Kay Devine \\ Athabasca University, \\ Edmonton, Alberta, Canada
}

kayd@athabascau.ca

\begin{abstract}
The primary aim of this study was to better understand the antecedents of doctoral students' emotional well-being, and their plans to leave academia. Based on past research, antecedents included departmental support, the quality of the supervisory relationship, and characteristics of the supervisory relationship. We used a mixed-methods study, and surveyed 186 doctoral students from nine countries. We found that supportive relationships, at the departmental and advisor level, reduced emotional exhaustion and intentions to leave academia, and that emotional exhaustion was positively related to doctoral students' intentions to leave academia. Findings also indicated that advisor experience and frequency of meetings reduced students' emotional exhaustion but did not affect their intentions to leave academia. Recommendations to reduce emotional exhaustion and to temper doctoral student attrition before and after degree completion are offered.
\end{abstract}

Keywords: Doctoral students, emotional exhaustion, attrition, support, supervision

\section{Introduction}

The decision to pursue a doctoral degree is considerable, given the time, resources, and commitment required. After admission, significant life changes often follow for students and their families. Furthermore, a typical doctoral program in North America takes five to seven years to complete, usually followed by two to four years of postdoctoral training in many of the sciences (Golde, 2001; Onwuegbuzie \& Wao, 2011). In Europe and Australia, the time to degree varies, with humanities doctorates taking the longest (Kehm, 2006) and average completion time of about seven years in England (Jump, 2013), and four years in Australia (Jiranek, 2010).

\section{Literature Review}

Material published as part of this publication, either on-line or in print, is copyrighted by the Informing Science Institute. Permission to make digital or paper copy of part or all of these works for personal or classroom use is granted without fee provided that the copies are not made or distributed for profit or commercial advantage AND that copies 1) bear this notice in full and 2) give the full citation on the first page. It is permissible to abstract these works so long as credit is given. To copy in all other cases or to republish or to post on a server or to redistribute to lists requires specific permission and payment of a fee. Contact Publisher@,InformingScience.org to request redistribution permission.
Despite the gravity of such a decision, research reveals that many students do not understand what doctoral training involves (Golde \& Dore, 2001), and consequently, students may be unprepared or poorly equipped to cope with the various challenges of their programs. Doctoral students have previously experienced high academic achievement (Ali \& Kohun, 2006; Lovitts, 2001), but many experience depression during their 
program due to financial stress, debt, isolation, thesis difficulties, and problems with their advisor (Ali \& Kohun, 2007; Delamont, Atkinson, \& Parry, 2004). Many doctoral students decide to abandon their studies: average rates of attrition in North American and Australian doctoral education have been reported to be as high as $50 \%$ for the past 50 years (Gardner \& Gopaul, 2012; Jiranek, 2010; Kerlin, 1995; Lovitts, 2001; Spaulding \& Rockinson-Szapkiw, 2012; Stallone, 2004), with a rate of 57\% in North America reported by the Council of Graduate Schools in 2008 (Gardner, 2009). Even where completion rates are higher, such as New Zealand (61\%) and the United Kingdom (72\%), there are still many who do not graduate (Jump, 2013).

Overall, it seems there is a dichotomy in doctoral student experiences: doctoral work can be a positive experience with intellectual and personal growth (Golde, 2001), thus contributing to student well-being, or it can be a negative experience, resulting in anxiety and emotional exhaustion (Pyhältö, Toom, Stubb, \& Lonka, 2012; Stubb, Pyhältö, \& Lonka, 2011). The intent of this research is to gain a better understanding of the negative factors that contribute to poor outcomes in doctoral education. We focus, in particular, on emotional exhaustion, a component of burnout that occurs when individuals experience a depletion of emotional energy and resources as a result of coping with high demands (Maslach \& Jackson, 1981). In the present study, a mixed methods research design is used to examine antecedents of doctoral student emotional exhaustion and plans to leave academia to better understand doctoral student attrition.

\section{Doctoral Student Persistence}

Early research on attrition determinants focused on student characteristics and found no meaningful differences between persistors and nonpersistors (Clewell, 1987). More recently, however, both individual and institutional factors have been examined (de Valero, 2001). For example, individual characteristics such as intellectual and psychological preparation (Hawley, 2003), demographic characteristics, financial means (Abedi \& Benkin, 1987), deficiencies (Green, 1997), stress (Jairam \& Kahl, 2012), social isolation (Gardner, 2007; Jairam \& Kahl, 2012) and the burden of the scholarly community (Stubb et al., 2011) have been found to contribute to attrition. Institutional characteristics also contribute to withdrawals, including the social structure and culture of graduate education (Lovitts, 2001), the socialization process (Gardner, 2008), program quality (Picciano, Rudd, Morrison, \& Nerad, 2008), and lack of support services (West, Gokalp, Vallejo, Fischer \& Gupton, 2011). In addition, the academic discipline or field of study also predicts attrition (Bair \& Haworth, 2005; Golde, 2005), with higher levels of attrition occurring in the social sciences and humanities, and lower levels in the sciences (e.g., Bair \& Haworth, 2005; Golde, 2005). Greater social interaction may contribute to higher completion rates in the laboratory sciences, where doctoral students benefit from the team atmosphere in the lab and have regular interaction with their advisor (Bauer, 1997). In contrast, doctoral students in the social sciences and humanities typically work in isolation and have less interaction with their advisor or other doctoral students (Bauer, 1997).

While many studies have examined patterns and predictors of success among doctoral students (e.g., Gardner, 2007; Hopwood, 2010; Jazvac-Martek, Chen, \& McAlpine, 2011; Jiranek, 2010; Martinuso \& Turkulainen, 2011), researchers have paid less attention to the well-being of graduate students. Pyhältö et al. (2012) analyzed factors that contribute to doctoral student achievement, and suggested that the context of a doctoral student's learning environment can either promote well-being and success, or can result in dysfunctional emotions and withdrawal. While a few recent studies have examined doctoral student well-being (e.g., Juniper, Walsh, Richardson, \& Morley, 2012; Rigg, Day, \& Adler, 2013; Stubb et al., 2011), our understanding of the factors that affect doctoral student well-being and persistence in academia remains incomplete. Consequently, the purpose of this study is to gain a better understanding of factors that affect doctoral students' emotional well-being and influence their intentions to leave academia. Among those 
factors to be explored, as suggested by past research, are emotional exhaustion, perceived departmental support, and some characteristics of the supervisory relationship. This research draws on several well-established theories and constructs from the organizational behavior literature, which complement traditional higher education perspectives and may promote different insights.

\section{Emotional Exhaustion and Attrition}

One approach to understanding the emotional well-being of doctoral students is to examine the extent to which they are experiencing emotional exhaustion. Emotional exhaustion is a core facet of burnout; it occurs when job demands exceed resources and results in a depletion of emotional energy (Brotheridge \& Lee, 2003; Maslach \& Jackson, 1981). People who are emotionally exhausted feel psychologically and emotionally drained, and may experience physical fatigue (Wright \& Cropanzano, 1998). In the workplace, emotional exhaustion is increased by time pressure, workload, lack of social support, lack of supervisor support, and role stress (Alarcon, 2011; Halbesleben, 2006; Lee \& Ashforth, 1996). Emotional exhaustion has many negative consequences, including reduced job satisfaction, lower organizational commitment, and weaker job performance (Alarcon, 2011; Cropanzano, Rupp, \& Byrne, 2003). Since individuals who experience prolonged or excessive emotional exhaustion look for a way to reduce their discomfort (Moore, 2000), emotional exhaustion is also positively related to turnover intentions (e.g., Alarcon, 2011; Cropanzano et al., 2003; Houkes, Janssen, de Jonge, \& Bakker, 2003; Lee \& Ashforth, 1996), and voluntary turnover (e.g., Wright \& Cropanzano, 1998).

Many of the workplace antecedents of emotional exhaustion are also present in the academic environment. The combination of low status, high workload, frequent evaluation, competition, insufficient supervisor support, and financial duress that employees experience are also common for doctoral students, and likely lead to stress (Kurtz-Costes, Helmke, \& Ulku-Steiner, 2006; Offsetin, Larson, McNeill, \& Mwale, 2004). Doctoral student well-being may also be affected by the socialization process and learning environment, which can vary significantly between departments and academic disciplines (Gardner, 2010; Golde, 2005). For example, doctoral students in the sciences typically have a more socially integrated learning environment in the laboratory, whereas students in the humanities are more isolated and solitary (Bauer, 1997; Golde, 2005). In a recent study by Stubb et al. (2011), many doctoral students felt excluded and marginalized, and reports of feeling unworthy were common. They found that weak or infrequent advising resulted in poor support for research, while limited access to quality courses, and a perceived lack of meaningfulness hindered doctoral student well-being.

Emotional exhaustion also appears to influence doctoral students' withdrawal intentions (Rigg et al., 2013). A recent study of Finnish doctoral students found that those who experienced higher anxiety and emotional exhaustion demonstrated lower interest in their studies and considered withdrawing from their program (Pyhältö et al., 2012). Therefore, it is expected that doctoral students who experience emotional exhaustion will be more likely to plan to leave academia, either before or after completing their degree.

Hypothesis 1: Emotional exhaustion will be positively related to doctoral students' intentions to leave academia.

\section{Perceived Department or Faculty Support}

The support that doctoral students receive from their department or faculty/school may affect their well-being and intentions to leave academia. The concept of perceived organizational support, which is readily adapted for different organizational foci such as a department or colleagues, provides insights on underlying mechanisms that might explain why departmental or faculty support contribute to unfavorable outcomes for doctoral students. Perceived organizational support, 
in organizational behavior research, reflects employees' beliefs about the extent to which their organization values their contribution and cares about their well-being; perceived organizational support is an important antecedent of employee performance, well-being, and turnover (Rhoades \& Eisenberger, 2002). Organizational support fulfills employees' socio-emotional needs by signaling that the organization cares about them, respects them, and approves of their performance, which has a favorable effect on employees' mood and job satisfaction (Baran, Shanock, \& Miller, 2012; Rhoades \& Eisenberger, 2002). Notably, several meta-analyses have demonstrated that perceived organizational support is negatively related to emotional exhaustion, burnout, strain, and turnover intentions (e.g., Baran et al., 2012; Cropanzano, Howes, Grandey, \& Toth, 1997; Rhoades \& Eisenberger, 2002). Research further suggests that employees who experience high levels of organizational support are less prone to aversive psychological reactions when they experience highly demanding or stressful work situations, because they believe the organization will offer emotional and material support to help them (Baran et al., 2012; Rhoades \& Eisenberger, 2002).

As members of the university organization, doctoral students are likely to form beliefs about the extent to which they are cared about and appreciated; however, they are more likely to focus on the department (or faculty) level, because it is more salient to them. Some scholars have concluded that research on doctoral student experiences should focus on departments within the academic institution, rather than the institution as a whole (Barnes \& Randall, 2012; Golde, 2005), as the policies that most affect students' lives are set at the department level (Golde, 2005). Lovitts and Nelson (2000) noted that, while the overall university may treat graduate students as disposable and replaceable, individual departments can take a different approach to make themselves more hospitable and supportive, and graduate most of their doctoral students. Indeed, Shelton (2003) found that perceived faculty support, both psychological and functional, was positively related to persistence among student nurses. Similarly, a meta-synthesis of doctoral student attrition demonstrated that faculty and departmental support were positively related to degree completion (Bair \& Haworth, 2005). Consequently, the extent to which the department or faculty offer support that satisfies doctoral students' socio-emotional needs, and the extent to which doctoral students feel recognized, appreciated, and cared about (i.e., the level of perceived department or faculty support), should affect their experiences of emotional exhaustion and influence their decisions regarding whether or not to continue in academia.

Hypothesis 2: Perceived department/faculty support will be negatively related to doctoral students' emotional exhaustion and intentions to leave academia.

\section{Leader Member Exchange}

The quality of the relationship between the doctoral student and the advisor plays an important role in doctoral student success (e.g., Lee, 2012; Lovitts, 2001; Wisker, 2012; Zhao, Golde, \& McCormick, 2007). As such, another well-established construct from organizational behavior may help characterize the supervisory relationship. The leader-member exchange construct (LMX) (Liden \& Maslyn, 1998), which assesses the quality of the relationship between a leader (i.e., supervisor) and a member (i.e., subordinate), is widely used in leadership research. Liden and Maslyn's (1998) multidimensional measure reflects four inter-related dimensions of the quality of the relationship including: (a) Contribution (the perception of the quality, amount, and direction of work-related activity that each member of the dyad directs towards achieving shared goals; (b) Loyalty (the extent to which each member of the dyad expresses public support for each other's character and actions); (c) Affect (mutual affection based on interpersonal attraction, rather than professional or work values); and (d) Professional respect (the extent to which each member of the dyad is perceived to have built a reputation of excellence in their work). 
The LMX model predicts that the relationship between the supervisor and subordinate develops over time as a function of the quality of their reciprocal exchanges and the degree of emotional support provided (e.g., Graen \& Scandura, 1987; Sparrowe \& Liden, 1997). The exchange relationships vary across a continuum; at one end, a high quality relationship develops between the individuals, and at the other end, a low quality relationship develops. In high quality LMX relationships, liking, loyalty, and respect are present (Van Dyne, Kamdar, \& Joireman, 2008), and increased communication and greater support reduce ambiguity and uncertainty for subordinates (Harris \& Kacmar, 2006). As a result, high quality LMX is consistently and favorably correlated with supervisory satisfaction, overall satisfaction, role perceptions, job performance, competence, commitment, and turnover intentions (Gerstner \& Day, 1997). Low quality LMX relationships are associated with a similar range of unfavorable outcomes and have a negative impact on employee well-being. It is also noteworthy that low quality LMX is positively related to emotional exhaustion (Lee \& Ashforth, 1996).

In university settings, the LMX framework has been used to study graduating students (Bauer \& Green, 1996) and new faculty members (Ugrin, Odom, \& Pearson, 2008). Although LMX has not previously been used in the context of the advisor-doctoral student dyad, the fact that it reflects several important dimensions of high quality supervisory relationships offers the potential for new insights into the supervisory relationship, which has been shown to play such a critical role in doctoral student success (e.g., Heath, 2002; Lee, 2012; Sambrook, Stewart, \& Roberts 2008; Wisker, 2012) and degree completion (Bair \& Haworth, 2005; Lovitts, 2001; Stallone, 2004).

While most agree on the importance of the advisor's role in doctoral education, in reality, there is a widespread problem of inadequate or inexperienced supervision (Delamont, et al., 2004; Shannon, 1995), and poor or problematic supervision is known to contribute to depression among graduate students (Delamont et al., 2004). Similarly, others have reported that the quality of the supervisory relationship affects students' anxiety, stress, and well-being (Stubb et al., 2011). Consistent with these findings, Pyhältö et al. (2012) found that doctoral students who experienced supervisory problems reported higher anxiety and emotional exhaustion, while Rigg et al. (2013) found that advisor support significantly reduced emotional exhaustion among American graduate students. The quality of the supervisory relationship also affects doctoral student commitment and persistence (Jones, 2011; Lovitts, 2001; Kurtz-Costes et al., 2006). Doctoral students who are dissatisfied with their advisor are more likely to consider quitting their program (Rigg et al., 2013) or actually withdraw (Lovitts, 2001).

Taken together, this suggests that the quality of the advisory relationship will affect doctoral students' emotional exhaustion and intentions to leave academia. As such, we expect:

Hypothesis 3: Leader-member exchange will be negatively related to doctoral students' emotional exhaustion and intentions to leave academia.

\section{Emotional Exhaustion as a Mediator}

Based on predictions that perceived department/faculty support, and leader-member exchange will reduce emotional exhaustion, and that emotional exhaustion will be positively related to intentions to leave academia, emotional exhaustion is expected to mediate the relationship between departmental and supervisory support, respectively, and intentions to leave academia.

Hypothesis 4a: The relationship between perceived department/faculty support and doctoral students' intentions to leave academia will be mediated by emotional exhaustion.

Hypothesis 4b: The relationship between leader-member exchange and doctoral students' intentions to leave academia will be mediated by emotional exhaustion. 


\section{Characteristics of the Supervisory Relationship}

As noted previously, one of the most powerful influences on doctoral student persistence is the relationship between the faculty advisor and the doctoral student (e.g., Barnes, 2010; de Valero, 2001; Lovitts, 2001; Sambrook et al., 2008). Leder (1995) suggested there is common agreement regarding the functions fulfilled by a doctoral advisor, including providing guidance, protection, sponsorship, information, support and encouragement, access to resources and opportunities, stimulating learning, and (intentionally or not) being a role model. Research has shown that the academic discipline influences behavioral norms among professors, particularly with respect to issues such as the treatment of students (Braxton \& Bayer, 1999). However, certain characteristics of the supervisory relationship, including the advisor's experience, whether or not the student chose the advisor, and the frequency of supervisory meetings may also affect doctoral students' emotional exhaustion and intentions to leave academia.

In addition to differences in supervisory style, advisors differ in the amount of experience they have. Lovitts (2001) noted that faculty who have supervised a high number of successful doctoral students interact with their students differently than faculty who have little supervisory experience. For example, she reported that highly experienced advisors were more likely to initiate interactions with students, to collaborate with them, and to help them find jobs (Lovitts, 2001). Likewise, Delamont et al. (2004) noted that, while problems during a student's doctoral program may be due to an inexperienced supervisor, most universities do not require that faculty have training in advising and mentoring. It follows that advisors with more experience supervising doctoral students are likely to maintain higher quality relationships with their students, which should have a positive effect on the students' emotional well-being and persistence in academia.

It also appears that doctoral students who choose their advisor are significantly more likely to persist and complete their program than students who are assigned an advisor (Lovitts, 2001). Lovitts suggests that most students do choose their advisor, and that this decision is often made on the basis of previous interactions (for example, in courses, or lab rotations) or similar research interests. Gardner (2007) also noted the importance of choosing the right advisor. To the extent that doctoral students are able to work with an advisor who has a complementary work style, a supportive supervisory style, and aligned research interests, students who choose their advisor should be less likely to experience emotional exhaustion or to plan on leaving academia.

Supervisory interaction and meetings are also a critical consideration in the advisory relationship. Both the frequency and quality of meetings are important (Li \& Seale, 2007). Although the quality and frequency of meetings likely varies with the individual advisor, it may also depend on the academic discipline. Gardner (2007) reported that doctoral students emphasized the importance of supervisory interaction, but she noted that expectations regarding contact time with their supervisor varied by academic department. Regardless, the frequency of interaction seems to affect doctoral student well-being and progress. For example, Stubb et al. (2011) found that weak and infrequent advising hindered the emotional well-being of doctoral students. Furthermore, students who have access to regular meetings with advisors, where they can receive guidance and discuss expectations, are more likely to complete their degrees (Bair \& Haworth, 2005). Taken together, we predict that:

Hypothesis 5a: Doctoral students who work with more experienced supervisors, who choose their supervisor, and who meet with their supervisor more often will report less emotional exhaustion.

Hypothesis 5b: Doctoral students who work with more experienced supervisors, who choose their supervisor, and who meet with their supervisor more often will report lower intentions to leave academia. 
The preceding hypotheses will be tested using a quantitative approach. However, we will use a qualitative approach to explore which types of supervisory interactions are most salient, and reasons why doctoral students change supervisors, which is likely to increase stress. Respondents' answers to open-ended comments will be examined in order to gain a more nuanced and richer understanding of factors that influence doctoral students perceptions of their relationship with their supervisor, which affects their well-being and intentions to leave academia.

\section{Methods}

\section{Sample and Procedure}

Doctoral students responded to a mixed methods survey that examined their perceptions of department/faculty support, leader-member exchange, emotional exhaustion, and intentions to leave academia. In addition to demographic characteristics, non-identifying information about their advisor and characteristics of their supervisory working relationship were collected. Both quantitative scale measures and qualitative systematic self-observation (SSO) items were included in the survey design in order to gather both a broad perspective of doctoral student experiences, and subtle details and stories of the respondents. The study design received human subjects ethics approval prior to recruiting respondents.

Participation was solicited in three ways: (1) through an international online community for graduate students; (2) via emails sent to graduate student associations requesting distribution of an invitation to participate; and (3) by asking participants to pass along the survey link to other eligible participants. As it cannot be determined how many people received an email or viewed the online invitation, the response rate cannot be estimated. Overall, 331 students from nine countries consented to participate in the study. After eliminating incomplete responses, the final sample consisted of 186 current or recently graduated doctoral students in research-based doctoral programs, yielding a completion rate of $56 \%$.

\section{Quantitative Measures}

The predictor variables included in the survey were perceived department/faculty support, leadermember exchange, and several characteristics of the advisor/student working relationship. Control variables included age, gender, and academic discipline (based on Biglan's (1973) hard/soft and pure/applied academic discipline classification scheme). Criterion variables included emotional exhaustion and intention to leave academia. For the quantitative items, unless otherwise specified, the measures, as defined below, consisted of 7-point Likert-style rating scales in which $1=$ strongly disagree, $2=$ disagree, $3=$ slightly disagree, $4=$ neither agree nor disagree, $5=$ slightly agree, $6=$ agree, and $7=$ strongly agree.

Perceived department/faculty support (PDS) was measured with six items adapted from the perceived organizational support scale (Eisenberger, Armeli, Rexwinkel, Lynch, \& Rhoades, 2001). The words "my department or faculty" were substituted for "my organization", to assess the extent to which respondents believed that their department or faculty cared about their well-being and appreciated their contributions (Eisenberger et al., 2001), (e.g., "My department or faculty really cares about my well-being").

Leader-member exchange, which reflects the quality of the relationship between the supervisor and the student, was measured using the 11-item scale from Liden and Maslyn (1998) (e.g., "my supervisor would come to my defense if I were 'attacked' by others").

Non-identifying information about the respondent's primary research advisor was collected, including the advisor's gender ( $46.8 \%$ female), and the advisor's prior experience supervising doc- 
toral students (measured as the number of doctoral students who successfully completed their degree with the advisor).

Respondents were also asked about various aspects of their working relationship with the advisor, such as whether the student had chosen the advisor, and meeting frequency. Respondents reported how frequently they met with their advisor in open-answer format, and these were recoded using a 9 point Likert-type scale $(1=$ never, $2=$ several times per year; $3=$ once per semester; $4=$ twice per semester, $5=$ monthly, $6=$ twice per month, $7=$ weekly, $8=$ twice per week, $9=$ daily).

Emotional exhaustion, which reflects the extent to which individuals feel emotionally and psychologically drained by their work, was measured with the 7-item scale from Maslach and Jackson (1981), (e.g., "I feel emotionally drained from my work").

Intention to leave academia was measured using three items adapted from Shore and Martin (1989), with a 5-point Likert-type response scale. "Academe" was substituted for "organization" in order to evaluate the extent to which participants intended to continue in academe (e.g., "If you were completely free to choose, would you prefer or not prefer to continue working in academe?"). Eight students (4.3\%) reported that they intended to leave academia before completing their degree, while 56 students $(30.3 \%)$ reported planning to leave academia after completing their degree.

\section{Demographics and Control Variables}

Demographic characteristics of respondents, specifically age $(\mathrm{M}=32.8, \mathrm{SD}=6.83)$, gender ( $80.6 \%$ female), and registration status (93.0\% full time) were collected. Respondents were from nine countries: Canada (58.7\%), United States (28.2\%), United Kingdom (4.9\%), Australia/New Zealand (2.4\%), Norway (2.4\%), France (0.5\%), and South Africa (0.5\%). Since respondents were from different countries (where different models of doctoral education are used), prior to aggregation, the data were checked for location effects. One-way analyses of variance (ANOVA) were conducted with the geographic location (North America, UK/Europe, NZ/Australia/Africa) as the grouping variable, and emotional exhaustion and intentions to leave academia as the criterion variables. As there were no significant country effects for either emotional exhaustion $(\mathrm{F}(2,176)=1.921, \mathrm{~ns})$ or intentions to leave academia $(\mathrm{F}(2,176)=.014, \mathrm{~ns})$, the data were aggregated.

In addition, respondents identified their academic discipline; this information was used to categorize respondents (Biglan 1973; 1= hard applied, 2= hard pure, $3=$ soft applied, 4= soft pure). Given Xu's (2008) conclusion that academic discipline must not be ignored in attrition research, it was used as a control variable in our analyses, with the soft pure discipline category used as the base case. Biglan's classification scheme consistently captures systematic differences among disciplines (Stoecker, 1993), and is one of the most widely used models for the study of disciplinary differences (Jones, 2011). The hard/soft dimensions of Biglan's classification scheme reflect the level of paradigmatic development in the field; that is, the extent to which scholars rely on a body of theory that accounts for phenomena of interest and promotes consensus. Hard disciplines (i.e., science-oriented areas) are characterized by high levels of paradigmatic development, whereas soft disciplines (i.e., humanities) have low levels of paradigmatic development, and social sciences are in the middle. The applied/pure dimension reflects the extent to which the discipline is concerned with practical application of the subject matter. Examples of highly applied disciplines include education, business, and engineering, while examples of pure disciplines include mathematics, philosophy, and history (Biglan, 1973). 


\section{Qualitative Measures}

In addition to the scales listed above, two open-ended qualitative items were included in order to gather richer, more descriptive data that might help to explain participant responses and experiences. A systematic self-observation (SSO) method was used, as it is recommended to gather information about those social actions that are hidden, restricted, or subjective, all of which are likely pertinent to doctoral student experiences. It also is useful to discern thoughts, emotions, and other criteria that are not always openly displayed (Rodriguez \& Ryave, 2002). In addition to understanding the quality of the supervisory relationship in general, we were also interested in specific examples of interactions that were particularly meaningful for students. Since changing supervisors is known to be a stressful event for doctoral students (Lovitts, 2001) and the supervisory relationship is important to emotional well-being, we also wanted to understand what types of issues contributed to students' decisions to change supervisors. As such, respondents were asked to recall instances related to significant interactions with their advisor, and to explain their reasons for changing advisors if they had done so. In addition, respondents were invited to comment, in general, about their doctoral experience. Specific open-ended questions on the survey included:

1. Please describe an interaction with your supervisor that had a significant impact on you (either positive or negative), and explain why it was significant.

2. If you have changed supervisors, please tell us why you changed supervisors.

We used thematic content analysis to analyze the qualitative answers. Responses to these queries were initially coded into themes by one of the researchers through numerous iterations of the data, and responses were subsequently grouped based on similarities. To heighten reliability and validity, a second researcher evaluated each response and indicated what theme it represented. Any differences that emerged were discussed until a consensus was reached on how a response should be categorized.

\section{Common Method Variance Analysis}

Although scale reliabilities for the established measures were strong, confirmatory factor analyses were used to verify the discriminant validity of the self-reported multi-item constructs and to assess the likelihood of common method variance (Podsakoff, MacKenzie, Lee, \& Podsakoff, 2003). The confirmatory factor analysis (CFA) was carried out using MPlus7 (Muthén \& Muthén, 2012). The validity of the measurement model was assessed using several different fit indices (Hu \& Bentler, 1999), including: root-mean squared error of approximation (RMSEA), using a criterion of $<.08$; comparative fit index (CFI) and Tucker-Lewis index (TLI), using a criterion of $>.9$; and a standardized root-mean-square residual (SRMSR), using a standard of $<.1$. The results showed that the hypothesized four-factor model, in which items were allowed to load only on their respective measure, demonstrated good fit to the data based on our criteria (RMSEA $=.07$, $\mathrm{CFI}=.92, \mathrm{TLI}=.91$, and $\mathrm{SRMR}=.07)$.

To assess the extent to which common method variance may have influenced results, a supplementary CFA for the multi-item measures was conducted (Podsakoff et al., 2003). The model specified the four theoretical latent factors, as well as a fifth CMV latent factor. All of the items were loaded to their theoretical latent constructs, and loaded several items from each theoretical construct to the latent method factor, as models in which all items are loaded to the latent method factor produce unidentifiable solutions (Spector \& Brannick, 2011). In examining the extent of CMV: (a) the overall fit of the model, (b) the variance in scale items explained by the theoretical and method factors, and (c) the significance of the loadings, were examined (e.g. Williams, Cote, $\&$ Buckley, 1989). The model converged, yielding the following fit statistics: RMSEA $=.13$, CFI $=.73, \mathrm{TLI}=.69 ;$ and $\mathrm{SRMR}=.17$. None of the items loaded significantly on the latent method 
factor. Furthermore, $47.9 \%$ of the variance in the scale items was explained by the theoretical factors, whereas only $0.5 \%$ of the variance was explained by the method factor. Hair, Anderson, Tatham and Black (1998) suggest that when more than $50 \%$ of the variance in the scale items is explained by the method factor, a single substantive factor is likely. As this result of $<1.0 \%$ is well below the $50 \%$ threshold, this suggests that common method variance was not a serious problem, thus we proceeded with hypothesis testing.

\section{Results}

The means, standard deviations, correlations, and alpha coefficients of internal reliability are provided in Table 1. Emotional exhaustion was negatively correlated with perceived department/faculty support, leader-member exchange, supervisory experience, and meeting frequency, and was positively correlated with gender (female) and intentions to leave academia. Intentions to leave academia were negatively correlated with age, soft pure academic disciplines, perceived department/faculty support, and leader-member exchange, and were positively correlated with hard applied academic disciplines. These correlation patterns were generally consistent with the hypotheses.

For descriptive purposes, in Table 2, we present a summary of variable means and standard deviations, and planned paired comparisons based on academic discipline categories. Results from univariate ANOVA analyses indicated that, for most variables, the means for the four academic discipline categories were not significantly different from each other, with the following exceptions: leaving intentions $(\mathrm{F}=4.85, \mathrm{p}<.01)$, where respondents in hard applied disciplines were more likely to intend to leave academia; choosing advisor $(F=2.91, p<.01)$, where respondents in hard pure disciplines were significantly more likely to have chosen their advisor; and meeting frequency $(\mathrm{F}=3.92, \mathrm{p}<.01)$, where respondents in hard applied and hard pure disciplines met more frequently with their advisors.

To test Hypothesis 1, we regressed leaving intentions on emotional exhaustion; these results are presented in Table 3. Hypothesis 1, which predicted that emotional exhaustion would be positively related to intentions to leave academia $(\beta=.37, \mathrm{p}<.001)$, was supported.

To test Hypotheses 2 and 3, we conducted separate hierarchical regression models, in which emotional exhaustion and intentions to leave academia were regressed, respectively, on perceived department/faculty support (PDS), leader-member exchange (LMX), and control variables. These results, jointly presented in Table 4, support Hypothesis 2, which posited that higher levels of PDS would be negatively related to emotional exhaustion $(\beta=-.18, p<.05)$ and intentions to leave academia $(\beta=-.16, \mathrm{p}<.05)$. Hypothesis 3 , which predicted that LMX would be negatively related to emotional exhaustion $(\beta=-.43, p<.001)$ and intentions to leave academia $(\beta=-.27, p$ $<.001)$, was also supported. 
Table 1. Means, standard deviations, scale reliabilities, and correlations

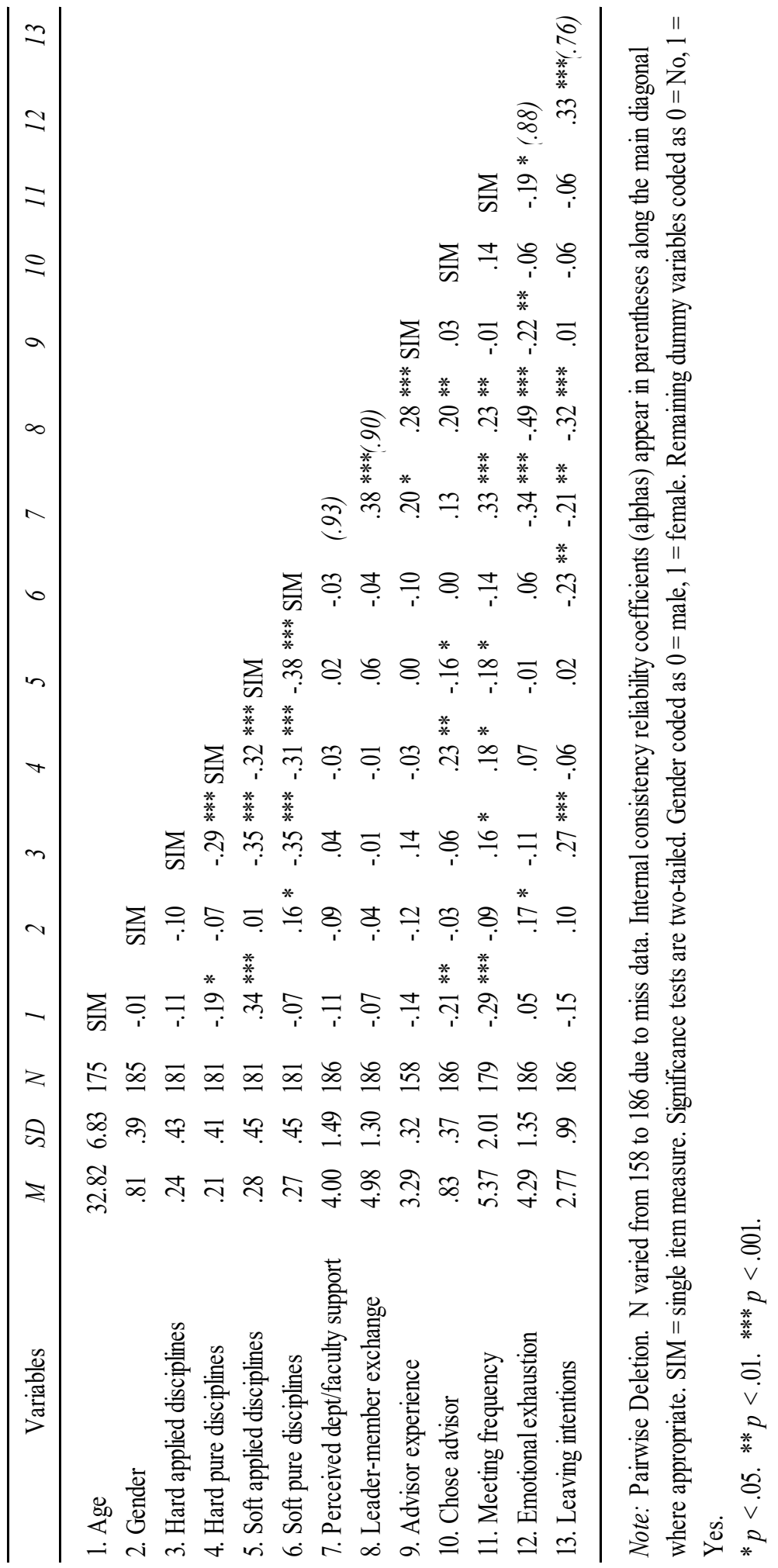


Table 2. Comparison of means and univariate ANOVA results for Biglan's discipline categories

\begin{tabular}{|c|c|c|c|c|c|c|c|c|c|}
\hline \multirow{2}{*}{$\begin{array}{c}\text { Biglan's Discipine } \\
\text { Category }\end{array}$} & \multirow[b]{2}{*}{$\mathrm{N}$} & \multicolumn{2}{|c|}{ PFS } & \multicolumn{2}{|c|}{ LMX } & \multicolumn{2}{|c|}{ Exhaustion } & \multicolumn{2}{|c|}{ Leaving Intentions } \\
\hline & & $M$ & $S D$ & $M$ & $S D$ & $M$ & $S D$ & $M$ & $S D$ \\
\hline Not Disclosed & 5 & 4.27 & .63 & 5.15 & 1.28 & 3.91 & .97 & 2.53 & .69 \\
\hline Hard Applied & 44 & $4.09^{\mathrm{a}}$ & 1.36 & $4.94^{\mathrm{a}}$ & 1.40 & $4.03^{\mathrm{a}}$ & 1.32 & $3.26^{\mathrm{a}}$ & .82 \\
\hline Hard Pure & 38 & $3.91^{\mathrm{a}}$ & 1.50 & $4.94^{\mathrm{a}}$ & 1.24 & $4.48^{\mathrm{a}}$ & 1.32 & $2.67^{b, c}$ & .99 \\
\hline Soft Applied & 50 & $4.04^{\mathrm{a}}$ & 1.60 & $5.10^{\mathrm{a}}$ & 1.37 & $4.27^{\mathrm{a}}$ & 1.56 & $2.81^{b, c}$ & 1.06 \\
\hline Soft Pure & 49 & $3.93^{\mathrm{a}}$ & 1.58 & $4.89^{\mathrm{a}}$ & 1.21 & $4.43^{\mathrm{a}}$ & 1.18 & $2.41^{\mathrm{b}}$ & .94 \\
\hline Total & 186 & 4.00 & 1.49 & 4.98 & 1.30 & 4.29 & 1.35 & 2.77 & .99 \\
\hline Univariate ANOVA & $F$ & .15 & & .21 & & .84 & & 4.85 & \\
\hline Biglan's Discipine & (varies) & Advis & Exp. & Chose & dvisor & $\mathrm{Mec}$ & ngs & & \\
\hline Category & $\mathrm{N}$ & $M$ & $S D$ & $M$ & $S D$ & $M$ & $S D$ & & \\
\hline Not Disclosed & & 4.50 & 4.36 & .80 & .45 & 5.20 & 2.05 & & \\
\hline Hard Applied & & $4.05^{\mathrm{a}}$ & 3.32 & $.80^{\mathrm{a}}$ & .41 & $5.93^{\mathrm{a}}$ & 1.98 & & \\
\hline Hard Pure & & $3.09^{\mathrm{a}}$ & 2.61 & $1.0^{\mathrm{b}}$ & .00 & $6.08^{\mathrm{a}}$ & 1.79 & & \\
\hline Soft Applied & & $3.24^{\mathrm{a}}$ & 3.69 & $.74^{\mathrm{a}}$ & .44 & $4.79^{\mathrm{b}}$ & 1.99 & & \\
\hline Soft Pure & & $2.75^{\mathrm{a}}$ & 2.97 & $.84^{\mathrm{a}}$ & .37 & $4.89^{\mathrm{b}}$ & 1.97 & & \\
\hline Total & & 3.29 & 3.20 & .83 & .37 & 5.37 & 2.01 & & \\
\hline Univariate ANOVA & $F$ & 1.02 & & 2.91 & & 3.92 & & & \\
\hline
\end{tabular}

Note: $N$ varied by category; some measures had missing data. Results of planned comparisons using Fisher's Least Significant Differences test are indicated with subscripts. Means in the same column with different subscripts are significantly different at $p<.05$.

$\mathrm{PFS}=$ perceived faculty support; LMX = leader-member exchange; Meetings = meeting frequency. ANOVA $F$-tests: $* p<.05 . * * p<.01 .{ }^{* * *} p<.001$.

Table 3. Hierarchical regression results for emotional exhaustion as an antecedent of intent to leave academia

\begin{tabular}{lccc}
\hline & \multicolumn{3}{c}{ Leaving Intentions } \\
\cline { 2 - 4 } & Model 1 & Model 2 & Model 3 \\
Predictor & $\beta$ & $\beta$ & $\beta$ \\
\hline Age & -.14 & $-.16^{*}$ & $-.18^{*}$ \\
Gender & .14 & $.17 *$ & .11 \\
Hard applied disciplines & & $.38^{* * *}$ & $.42 * * *$ \\
Hard pure disciplines & & .06 & .04 \\
Soft applied disciplines & & $.24 * *$ & $.26 * *$ \\
Emotional Exhaustion & & & $.37 * * *$ \\
& & & \\
$F$ & $3.26 *$ & $6.02 * * *$ & $10.89 * * *$ \\
$R^{2}$ & .04 & .15 & .28 \\
Adjusted $R^{2}$ & .03 & .13 & .26 \\
$\Delta R^{2}$ & $.04 *$ & $.12 * * *$ & $.13 * * *$ \\
\hline
\end{tabular}

Note. $N=172$, with listwise deletion. Standardized parameter estimates are presented. Gender coded as $0=$ male, $1=$ female.Academic discipline dummy variables coded as $0=$ No, $1=$ Yes; soft pure discipline used as the base case.

$* \mathrm{p}<.05$. ** $\mathrm{p}<.01$. *** $\mathrm{p}<.001$. 
Table 4. Hierarchical regression results for antecedents of emotional exhaustion and intent to leave academia

\begin{tabular}{|c|c|c|c|c|c|c|}
\hline \multirow[b]{2}{*}{ Predictor } & \multicolumn{3}{|c|}{ Emotional Exhaustion } & \multicolumn{3}{|c|}{ Leaving Intentions } \\
\hline & $\begin{array}{c}\text { Model } 1 \\
\beta\end{array}$ & $\begin{array}{c}\text { Model } 2 \\
\beta\end{array}$ & $\begin{array}{c}\text { Model } 3 \\
\beta \\
\end{array}$ & $\begin{array}{c}\text { Model } 1 \\
\beta\end{array}$ & $\begin{array}{c}\text { Model } 2 \\
\beta\end{array}$ & $\begin{array}{c}\text { Model } 3 \\
\beta \\
\end{array}$ \\
\hline Age & .04 & .06 & -.01 & -.14 & $-.16 *$ & $-.21 * *$ \\
\hline Gender & $.17 *$ & $.16 *$ & .12 & .14 & $.17 *$ & $.15 *$ \\
\hline Hard applied disciplines & & -.10 & -.09 & & $.38 * * *$ & $.39^{* * *}$ \\
\hline Hard pure disciplines & & .04 & .03 & & .06 & .05 \\
\hline Soft applied disciplines & & -.06 & .00 & & $.24 * *$ & $.27 * *$ \\
\hline Perceived department/faculty support & & & $-.18 *$ & & & $-.16 *$ \\
\hline Leader-member exchange & & & $-.43 * * *$ & & & $-.27 * * *$ \\
\hline$F$ & 2.53 & 1.48 & $10.97 * * *$ & $3.26 *$ & $6.02 * * *$ & $9.29 * * *$ \\
\hline$R^{2}$ & .03 & .04 & .32 & .04 & .15 & .28 \\
\hline Adjusted $R^{2}$ & .02 & .01 & .29 & .03 & .13 & .25 \\
\hline$\Delta R^{2}$ & .03 & .01 & $.28 * * *$ & $.04 *$ & $.12 * * *$ & $.13^{* * *}$ \\
\hline
\end{tabular}

Note. $N=172$, with listwise deletion. Standardized parameter estimates are presented. Gender coded as $0=$ male, $1=$ female. Academic discipline dummy variables coded as $0=$ No, $1=$ Yes; soft pure discipline used as the base case.

$* \mathrm{p}<.05 .{ }^{* *} \mathrm{p}<.01 .{ }^{* * *} \mathrm{p}<.001$.

To test Hypotheses $4 \mathrm{a}$ and $4 \mathrm{~b}$, and to determine whether emotional exhaustion mediated the relationship between perceived department/faculty support or leader member exchange, and intentions to leave academia (controlling for age, gender, and academic discipline), we followed the advice of Preacher and Hayes (2008), and modelled bias-corrected bootstrapped estimates of direct and indirect effects in MPlus, using 5000 bootstrap samples. The 95\% confidence interval for the fully standardized specific indirect path between PFS and leaving intentions, via emotional exhaustion, was -.08 to .00 , ns, thus emotional exhaustion did not mediate the relationship between PFS and leaving intentions, and Hypothesis 4a was not supported. The confidence interval for the fully standardized specific indirect path between LMX and leaving intentions, through emotional exhaustion, was -.16 to $-.03, \mathrm{p}<.01$, indicating that emotional exhaustion mediates the relationship between LMX and leaving intentions. Hypothesis $4 \mathrm{~b}$ was therefore supported.

Testing Hypotheses $5 \mathrm{a}$ and $5 \mathrm{~b}$ required hierarchical regression analyses examining the relationship between supervisory relationship characteristics and the criterion variables; results are presented in Table 5. The advisor's experience $(\beta=-.23, p<.01)$ and meeting frequency $(\beta=-.20, p$ $<.05)$ significantly reduced emotional exhaustion, thus Hypothesis 5 a was partially supported. Although some of the control variables were significantly related to intentions to leave academia, none of the characteristics of the supervisory relationship was significantly related to leaving intentions. Thus, Hypothesis $5 \mathrm{~b}$ was not supported. 
Table 5. Hierarchical regression results for supervisory relationship characteristics as antecedents of emotional exhaustion and intent to leave academia

\begin{tabular}{|c|c|c|c|c|c|c|}
\hline \multirow[b]{2}{*}{ Predictor } & \multicolumn{3}{|c|}{ Emotional Exhaustion } & \multicolumn{3}{|c|}{ Leaving Intentions } \\
\hline & $\begin{array}{c}\text { Model } 1 \\
\beta\end{array}$ & $\begin{array}{c}\text { Model } 2 \\
\beta\end{array}$ & $\begin{array}{c}\text { Model } 3 \\
\beta\end{array}$ & $\begin{array}{c}\text { Model } 1 \\
\beta\end{array}$ & $\begin{array}{c}\text { Model } 2 \\
\beta\end{array}$ & $\begin{array}{c}\text { Model } 3 \\
\beta\end{array}$ \\
\hline Age & .01 & .03 & -.07 & -.13 & -.13 & -.18 \\
\hline Gender & .15 & .14 & .13 & .14 & $.20 *$ & $.20 *$ \\
\hline Hard applied disciplines & & -.09 & -.02 & & $.40 * * *$ & .44 \\
\hline Hard pure disciplines & & .09 & .12 & & .11 & .13 \\
\hline Soft applied disciplines & & -.05 & -.02 & & .20 & $.23 *$ \\
\hline Advisor's experience & & & $-.23 * *$ & & & -.11 \\
\hline Advisor chosen by student & & & -.03 & & & .02 \\
\hline Frequency of meetings & & & $-.20 *$ & & & -.14 \\
\hline$F$ & 1.58 & 1.28 & $2.27 *$ & 2.56 & $4.66 * *$ & $3.43 * *$ \\
\hline$R^{2}$ & .02 & .05 & .12 & .04 & .15 & .17 \\
\hline Adjusted $R^{2}$ & .01 & .01 & .07 & .02 & .12 & .12 \\
\hline$\Delta R^{2}$ & .02 & .01 & $.08 *$ & .04 & $.11 * *$ & .03 \\
\hline
\end{tabular}

Note. $N=140$, with listwise deletion. Standardized parameter estimates are presented. Gender coded as $0=$ male, $1=$ female. Academic discipline dummy variables coded as $0=$ No, $1=$ Yes; soft pure discipline used as the base case.

$* \mathrm{p}<.05$. ** $\mathrm{p}<.01$. *** $\mathrm{p}<.001$.

\section{Qualitative, Systematic Self-Observation Theme Summary}

Although we did not pose formal hypotheses regarding the nature of supervisory interactions and reasons for changing supervisors, gathering information on these issues in a qualitative approach provides greater contextual detail in understanding the doctoral student experience. Table 6 presents the themes that emerged in the open-ended SSO responses with respect to interactions with the supervisor and reasons for changing supervisor, and presents illustrative textual examples of responses. Overall, respondents indicated more positive than negative instances of interaction with their supervisor, and most instances of changing supervisors were due to neutral reasons like a move or retirement, or were due to a mismatch. 
Table 6. Themes, relative frequency, and illustrative quotes

\begin{tabular}{|c|c|}
\hline Response Topic (Frequency) & Textual Illustration \\
\hline \multicolumn{2}{|l|}{ 1. Positive Supervisor Interaction } \\
\hline Protects, advises, trains $(32 \%)$ & $\begin{array}{l}\text { When another faculty asked me to do something unreasonable for a } \\
\text { paper I was writing, she talked to the department chair about it, as } \\
\text { well as the faculty member in question. }\end{array}$ \\
\hline Psychological support (31\%) & $\begin{array}{l}\text { My supervisor is able to accept that I am discouraged and does not } \\
\text { judge me for it. He focuses on moving forward and encourages me to } \\
\text { do the same... }\end{array}$ \\
\hline Honest interaction/feedback (15\%) & $\begin{array}{l}\text { After spending ages working on a paper which he was incredibly } \\
\text { fussy about the quality of the writing, I made some comment about } \\
\text { his being a tough reviewer. He said that he went easier in journal re- } \\
\text { views but that he wanted me to be able to look back at my PhD papers } \\
\text { and be proud of them. That idea has always encouraged me to take } \\
\text { that kind of pride in my papers and put effort into writing them well. }\end{array}$ \\
\hline Good working relationship (10\%) & $\begin{array}{l}\text { He has really been there for me to go through the growing pains of } \\
\text { learning how to think and learn differently. }\end{array}$ \\
\hline Financial support (6\%) & $\begin{array}{l}\text { My supervisor was very willing to be flexible with working hours, so } \\
\text { that I could 'build up' time by working extra hours one month in or- } \\
\text { der to get paid consistently during the following month when I was } \\
\text { out of town }\end{array}$ \\
\hline Provides passion/enthusiasm (6\%) & My continual interactions with my supervisor inspire me. \\
\hline \multicolumn{2}{|l|}{ 2. Negative Supervisor Interaction } \\
\hline $\begin{array}{l}\text { Lack of responsibility; disor- } \\
\text { ganized }(22 \%)\end{array}$ & $\begin{array}{l}\text { He is unable to keep everything in order; he has hired too many grad- } \\
\text { uate students and cannot look after their projects. }\end{array}$ \\
\hline Too critical \& demanding (16\%) & $\begin{array}{l}\text { My supervisor says that he pushes me harder because I can do more. } \\
\text { It can be demoralizing never to hear any good feedback. }\end{array}$ \\
\hline $\begin{array}{l}\text { Lack of communication; good } \\
\text { manners }(16 \%)\end{array}$ & $\begin{array}{l}\text { Overall, I have an incredibly poor relationship with my co- } \\
\text { supervisors... what made a great impact on me was that they purpose- } \\
\text { fully closed an elevator door in my face to avoid having to ride in the } \\
\text { elevator with me. }\end{array}$ \\
\hline Mistreatment/abuse $(15 \%)$ & $\begin{array}{l}\text { My supervisor is a very intelligent researcher, but was often verbally } \\
\text { abusive, used public humiliation as a control technique... }\end{array}$ \\
\hline Too territorial $(13 \%)$ & $\begin{array}{l}\text { I was trying to run some analyses in another lab. The professor in } \\
\text { charge of that lab was willing to help me out, however he requested } \\
\text { collaborative work in exchange (i.e. to be co-author). My supervisor } \\
\text { didn't like the idea and the samples were not analyzed. }\end{array}$ \\
\hline $\begin{array}{l}\text { Does not defend or provide guid- } \\
\text { ance }(13 \%)\end{array}$ & $\begin{array}{l}\text { My dissertation director approved my chapter and later removed ap- } \\
\text { proval after another member of my committee did not like the chap- } \\
\text { ter. I felt betrayed by his failure to stand up for me. }\end{array}$ \\
\hline Lack of interest (4\%) & $\begin{array}{l}\text { Being an international student, I had a number of challenges to face. } \\
\text { The worst was working with a supervisor who preferred to support } \\
\text { trainees from certain countries but not others. }\end{array}$ \\
\hline
\end{tabular}




\begin{tabular}{|l|l|}
\hline Response Topic (Frequency) & Textual Illustration \\
\hline Lack of trust (2\%) & $\begin{array}{l}\text { I had an idea for research. I told my supervisor...and we came up } \\
\text { with some ways of testing it...He told me he decided to submit the } \\
\text { manuscript as the only author... This experience has left me not trust- } \\
\text { ing my supervisor and I will not share research ideas with him again. }\end{array}$ \\
\hline 3. Reason for Change of Supervisor \\
\hline Supervisor left or retired (23\%) & (My) former supervisor left the university \\
\hline $\begin{array}{l}\text { Mismatch in interest area or re- } \\
\text { search approach (21\%) }\end{array}$ & My project expanded out of her area of expertise... \\
\hline Lack of guidance (17\%) & $\begin{array}{l}\text { Poor treatment, lack of communication, supervisor lost interest in me } \\
\text { and led me down the wrong path }\end{array}$ \\
\hline $\begin{array}{l}\text { Fear of supervisor; harassment; } \\
\text { poor treatment (17\%) }\end{array}$ & $\begin{array}{l}\text { He treated me very poorly overall to the point where I was literally } \\
\text { afraid of him. }\end{array}$ \\
\hline $\begin{array}{l}\text { Personality/ethics/working style } \\
\text { differences (13\%) }\end{array}$ & $\begin{array}{l}\text { Incompatible sense of ethics; was tired of being lied to and directed to } \\
\text { do unethical things }\end{array}$ \\
\hline Supervisor not available (6\%) & $\begin{array}{l}\text { He would leave the country for several weeks/the entire summer } \\
\text { without informing me about his absence }\end{array}$ \\
\hline Competency of supervisor $(4 \%)$ & First supervisor was too busy and their research was poor quality \\
\hline
\end{tabular}

\section{Advisor Interaction}

The first open-ended item asked students to "describe an interaction with your advisor that had a significant impact on you, and explain why it was significant for you." The item was deliberately worded so that any type of interaction - positive or negative - could be described. Overall, 139 respondents described an advisor interaction that was significant to them. Of these, 86 were positive incidents, while 53 were negative. Within the positive responses, most related to the theme that the advisor protected the student and provided good advice and training $(n=28)$. The next most common theme was of advisors who supported, encouraged, and recognized student achievements $(\mathrm{n}=27)$. For example, for the most often mentioned theme ("protects, advises, and trains") stories emerged such as: "When another Faculty asked me to do something unreasonable for a paper I was writing, she talked to the department chair about it, as well as the Faculty member in question," or "My supervisor really helped me to develop skills outside my area of expertise and to develop 'soft' skills like organizing conferences ..."

In terms of the second highest theme ("psychological support, encouragement, and recognition"), one student commented "My supervisor always gave full credit to the graduate students for the success of their research program ..." while another stated "My current supervisor often praises my work, which I find significant every single time ... [she] will critique as well ... and helps me see where the weaknesses in my argument lie". Perhaps one of the most positive comments was from a student who reported:

My supervisor defended me to my committee when my old supervisor had doubts about my ability to succeed in the program. My "new" supervisor told me "I believe in you, you can do this". It was a life-changing moment and no one had ever told me that before. I needed that support and encouragement to keep going.

In contrast, the highest number of negative comments revolved around a theme of the advisor being disorganized and lacking responsibility: "He is unable to keep everything in order", and "My advisor was going on sabbatical for the fall semester and did not properly notify her advisees. I learned of it through an email to the listserv." Another commented, "Printing 200 exams 
in my office the night before a final at 2 am. It showed me again my supervisor's consistent disorganization ..."

\section{Reason for Changing Advisors}

The second open-ended item asked students who had reported changing supervisors to explain why they did so, as this is likely a stressful event which affects students' emotional exhaustion. Among the respondents were some who changed advisors after beginning their doctoral studies (n $=48)$. The largest group $(n=11)$ were those who had no choice because their advisor had left the position due to a job change or retirement. This indicates that despite the number of comments related to negative experiences with an advisor, very few doctoral students actually changed supervisors by choice. Of those who did make a change, however, most were due to either a mismatch with the advisor at the outset $(n=10)$ or poor treatment $(n=8)$. Those who stated a mismatch were fairly straightforward and objective about their change. In contrast, those who discussed poor treatment were much more colorful. For example, "She was a terrible human being ..." or "The first supervisor I worked with was a bully ... I realized that to continue in academe that I had to change supervisors. It was messy ..." Another student commented:

Incompatible sense of ethics, was tired of being lied to and directed to do unethical things. He would leave the country for several weeks/the entire summer without informing me about his absence. He treated me very poorly overall to the point where I was literally afraid of him.

Finally, one student commented on a first advisor:

The abuse I experienced is hard to characterize, especially in a survey form. It took me a long time to understand what was going on because its style was so insidious - being told that to survive in this profession one had to sleep 4 hours a night, or give one's whole life, 12-hour days at full speed to the profession.

\section{Discussion}

The primary objective of this study was to gain a better understanding of the factors that contribute to doctoral students' emotional exhaustion and intentions to leave academia. Approximately one third of doctoral student respondents (35.5\%) reported moderate to high levels of emotional exhaustion; this finding suggests that emerging concerns about doctoral students' emotional wellbeing (e.g. Pyhältö et al., 2012; Stubb et al., 2011) are well-founded.

Students who reported higher levels of emotional exhaustion were more likely to plan on leaving academia. This relationship between emotional exhaustion and intentions to leave academia is consistent with Pyhältö et al.'s (2012) finding that exhaustion, stress, and anxiety were significantly higher among doctoral students who had considered withdrawing from their program. Respondents' intentions to leave academia were significantly predicted by their age and academic discipline. Age was negatively related to leaving intentions, which suggests that the greater work and life experience older students may provide them with stronger communication or coping skills to better manage the challenges of doctoral studies. Doctoral students in hard applied and soft applied academic disciplines were more likely to plan on leaving academia. The higher education literature reports that some academic disciplines have different labor market opportunities, both inside and outside academia (e.g., Xu, 2008; Zhou \& Volkwein, 2004), and applied disciplines may offer attractive job opportunities outside academia. Although others have reported that attrition tends to be higher among female doctoral students (Lovitts, 2001) and faculty members (Zhou \& Volkwein, 2004), gender did not influence leaving intentions in this sample. 
Perceived departmental/faculty support significantly reduced doctoral students' emotional exhaustion. As a proximate academic community, the department plays a focal role in doctoral students' educational experience (Gardner, 2010), and it appears that feeling cared about and appreciated at the departmental (or faculty) level has positive effects on doctoral students' emotional exhaustion. Perceived departmental/faculty support was also negatively related to intentions to leave academia. Consistent with findings reported elsewhere (e.g., Bair \& Haworth, 2005; Lovitts, 2001), doctoral students who experienced high levels of faculty/department support were less likely to plan on leaving academia, controlling for age, gender, and academic discipline. As our measure of leaving intentions also encompassed intentions to leave academia after graduation, one possible interpretation of these results is that the level of support received from the broader group (as opposed to the dyadic supervisory relationship) informs doctoral students' understanding of the types of relationships and support that can generally be found within academic departments - this information may allow them to self-select out of a career in academia if they find that the department or faculty environment is not likely to provide the type of support they anticipate wanting during their career.

While the importance of high quality supervisory relationships is widely acknowledged in the literature (e.g., Bair \& Haworth, 2005; Lovitts, 2001), this study is the first, to our knowledge, to demonstrate that LMX has a positive effect on doctoral students' emotional exhaustion. The multiple dimensions of LMX (contribution, loyalty, affect, and professional respect) may lead to new insights for improving the supervisory relationship.

Our hypotheses regarding mediation effects received mixed support. Contrary to expectations, emotional exhaustion did not mediate the relationship between perceived faculty/department support and leaving intentions. However, our prediction that emotional exhaustion would mediate the relationship between LMX and leaving intentions was supported. Although both sources of support were negatively related to emotional exhaustion and intentions to leave academia, our results suggest that the supervisory relationship is more salient to doctoral student emotional exhaustion and leaving intentions than departmental/faculty support. This result is consistent with others' findings that the quality of the supervisory relationship is crucial to a variety of doctoral student outcomes (e.g., Delamont et al., 2004; Jones, 2011; Lovitts, 2001; Kurtz-Costes et al., 2006; Rigg et al., 2013; Stubb et al., 2011; Pyhältö et al., 2012).

Some characteristics of the supervisory working relationship also appear to affect doctoral students' emotional exhaustion; the more students a doctoral advisor has successfully seen through to completion, and the more frequently students meet with their advisor, the lower the doctoral student's emotional exhaustion. These results are consistent with prior findings that the supervisor's experience and accessibility play a key role in doctoral student satisfaction and well-being (Gardner, 2005; Lovitts, 2001; Stubb et al., 2012). Contrary to expectations and Lovitts' (2001) previous findings, none of the characteristics of the supervisory working relationship significantly affected intentions to remain in academia. While this may reflect students' ability to recognize that a poor working relationship with their supervisor during their doctoral studies will not necessarily reflect their future experiences in academia, it may also be an artifact of the way that leaving intentions was measured in our study, and suggests that future research should distinguish between intentions to leave during the doctoral program (i.e. program attrition), and intentions to leave academia after the doctorate (i.e, career attrition).

Respondents' answers to open-ended SSO questions offer additional insights into their experiences as doctoral students. When asked to comment on significant interactions with their advisor, $62 \%$ focused on positive experiences, speaking to the positive impact of their advisor's efforts to train, advise, and protect them, and the importance of support, encouragement, and recognition they receive from their advisor. The students who reported a negative interaction spoke to the 
disorganization and lack of responsibility demonstrated by their advisor, and a small number reported mistreatment and abuse.

Approximately one quarter of the respondents reported changing advisors at some point during their program, predominantly due to neutral reasons such as the advisor's retirement or departure, or due to a mismatch of research interests or working styles. These results are largely consistent with the extant literature. For example, Lovitts (2001) reported that approximately $31 \%$ of doctoral students in her study changed supervisors. Similarly, reasons for changing supervisors parallel other reports that incompatibility can result as a function of process; for example, when advisors insist that a student conduct research in the advisor's area of interest rather than the student's (Leder, 1995), or as a function of different cognitive styles (Armstrong, Allinson, \& Hayes, 2004). Incompatibility may also arise in the extreme case of faculty incivility or bullying (Twale \& DeLuca, 2008), and eight instances of students changing advisors because of mistreatment were revealed in the survey.

This study identifies some key correlates of doctoral students' emotional exhaustion and intentions to leave academia, and our findings have several practical implications.

\section{Practical Implications}

This research suggests that improving the quality of relationships that doctoral students have with their advisor, and with their department/faculty, would have beneficial effects on doctoral students' emotional exhaustion and intentions to continue in academe. This points to the importance of providing doctoral students with a supportive environment and an advisor who is both willing and able to foster the development of a high quality exchange relationship with the students he or she supervises. While professors are highly trained in research, few receive explicit training in the area of mentoring and supervision, responsibilities that are central to high quality relationships. Additionally, creating a structured model to assist advisors in providing feedback, both in terms of academic research and relationship management, may be helpful. Accordingly, universities should consider implementing a mentor training and development program for faculty who serve as doctoral student advisors. Bair and Haworth (2005) have suggested that tenure and merit policies should reward faculty for involvement with doctoral students, and should be accompanied by faculty workload policies that protect doctoral students' interests and ensure that faculty have sufficient time for them. Further, such policies should be structured to promote high quality supervision by engaged faculty members. The development of a code of ethics that establishes professional standards for supervision and mentoring may also be helpful.

Emphasizing to students that choosing an advisor is a crucial decision, and helping them find an advisor and develop a positive working relationship would also be beneficial. Doctoral students may also benefit from training in communication and conflict management strategies in order to more successfully manage this core relationship. The findings also highlight the importance of helping doctoral students develop functional coping skills that would either prevent or reduce the experience of emotional exhaustion. Doctoral students should be encouraged to develop some measure of psychological detachment from their work; for example, by implementing boundaries to separate work and non-work times (Sonnentag, Kuttler, \& Fritz, 2010).

In the event that the supervisory relationship is not working in the best interests of the doctoral student or the advisor, clear communication regarding changing supervisors is warranted. Lovitts (2001) reports that students perceive changing advisors to be politically sensitive, which may preclude their changing advisors even when it would be in their best interest, personally and professionally, to do so. Doctoral students would therefore benefit from policies and processes that both support and assist them in changing advisors, when necessary or appropriate, without fear of repercussion. 
Although the length of time and level of commitment required in doctoral programs are extensive, Golde and Dore (2001) report that many students do not understand what is involved in doctoral training. The lack of information suggests that unrealistic expectations and incomplete information are likely a problem for many students early in their doctoral program, and point to the need for careful orientation and socialization of doctoral students. Weidman and Stein (2003) report that doctoral students' perceptions of faculty encouragement are related to their socialization to the scholar role, and the extent to which the department fosters collegial relationships and encourages student participation. Klomparens and Beck (2004) have suggested that mutually understood expectations are critical to doctoral student success. Given that unmet expectations may affect both well-being (i.e. emotional exhaustion) and attrition intentions, it may be appropriate for advisors to work with individuals to reframe unmet expectations as learning opportunities (Proost, van Ruysseveldt, \& van Dijke, 2012). Similarly, unmet expectations might be further reduced if graduate programs recommend that advisors and students develop an explicit psychological contract, in which the expectations and obligations of both parties are clearly specified (Rousseau, 1996; Wade-Benzoni, Rousseau, \& Li, 2011).

\section{Limitations and Recommendations for Future Research}

As with all research, several limitations are present in this study. First, as the results presented here are based on correlational data, no conclusions can be drawn regarding causal relations; a longitudinal design would be appropriate for future research. Second, the use of self-report measures raises potential concerns about social desirability response bias and common method variance (CMV). Ideally, independent raters would have been used for some of the measures. However, the nature of the learning environment and the socialization process create strong incentives for doctoral students to be secretive about emotional exhaustion and their intentions to leave academia, as disclosing this information could have negative repercussions on their program progression and career options upon graduation. To reduce the likelihood of social desirability response biases, respondents were assured anonymity, any items based on the reported constructs were not labelled, and scale items in the questionnaire were separated to make it harder for respondents to guess the relationship between the variables (Podsakoff et al., 1993). Statistical analysis techniques suggested that the observed relationships among the variables are not due to common method variance.

Third, the characteristics of this sample may have contributed to the non-findings with respect to determinants of attrition. Only $4.3 \%$ of respondents indicated that they planned to withdraw from their program without completing their degree; this rate of anticipated attrition is considerably lower than published statistics, and therefore there exists the possibility of a self-selection bias in the sample, such that those students who were most likely to quit their program and were most likely to be severely burned out, emotionally exhausted, disengaged, or angry, either chose not to participate or had already left their degree programs. A higher percentage $(30.3 \%)$ reported planning to leave academia after completing their degree, with approximately half of them reporting that their career objective was with government or industry. This suggests that some of them may have always intended to leave academia after completing their degree, in which case positive or negative experiences in graduate school may not have contributed to their intentions to leave. Informal examination of open ended comments at the end of the survey suggests that study respondents reflect a broad range of satisfaction levels, including students who were happy with their experiences as well as those who were angry or bitter about their graduate student experiences.

Finally, although our study examined the prevalence and antecedents of emotional exhaustion, it did not examine whether resources are available to help students cope with the various facets of burnout (including emotional exhaustion). It would therefore be appropriate for future work on 
doctoral student well-being to examine the efficacy of various resources in ameliorating emotional exhaustion among individuals experiencing burnout.

Future work should continue to assess doctoral student emotional exhaustion, but should also examine other aspects of emotional well-being, including general mental health, stress and anxiety, depression, sleep disturbances, resilience, happiness, self-esteem, and so forth. We suggest that data collected from both doctoral students and advisors would be helpful, and would also encourage researchers to examine a broader range of correlates, including funding support, program stage, career objectives, coping skills, and student performance. Longitudinal research would also be valuable, as students' perceptions and concerns may vary as a function of their program stage.

\section{Conclusion}

This study examined a number of factors thought to influence doctoral students' emotional exhaustion and intent to remain in academia. Emotional exhaustion is significantly lower among doctoral students who receive high levels of support from their faculty/school, have high quality supervisory relationships, and who work with more experienced doctoral advisors. Open-ended comments also confirmed that nature of the relationship they have with their advisor has a meaningful impact on doctoral students. These findings offer a solid basis for future scholarly work, and identify a number of practical changes that universities could implement to help reduce emotional exhaustion and promote retention of their doctoral students.

\section{References}

Abedi, J., \& Benkin, E. (1987). The effects of students' academic, financial, and demographic variables on time to the doctorate. Research in Higher Education, 27(1), 3-14. doi: 10.1007/BF00992302

Alarcon, G. M. (2011). A meta-analysis of burnout with job demands, resources, and attitudes. Journal of Vocational Behavior, 79(2), 549-562. doi: 10.1016/j.jvb.2011.03.007

Ali, A., \& Kohun, F. (2006). Dealing with isolation feelings in IS doctoral programs. International Journal of Doctoral Studies, 1, 21-33. Retrieved from http://www.iids.org/Volume1/IJDSv1p021-033Ali13.pdf

Ali, A., \& Kohun, F. (2007). Dealing with social isolation to minimize doctoral attrition - a four stage framework. International Journal of Doctoral Studies, 2, 33-49. Retrieved from http://ijds.org/Volume2/IJDSv2p033-049Ali28.pdf

Armstrong, S. J., Allinson, C. W., \& Hayes, J. (2004). The effects of cognitive style on research supervision: A study of student-supervisor dyads in management education. Academy of Management Learning \& Education, 3(1), 41 - 63. doi: 10.5465/AMLE.2004.12436818

Bair, C. R., \& Haworth, J. G. (2005). Doctoral student attrition and persistence: A meta-synthesis of research. In J. C. Smart (Ed.), Higher education: Handbook of theory and research (pp. 481-534). The Netherlands: Springer.

Baran, B. E., Shanock, L. R., \& Miller, L. R. (2012). Advancing organizational support theory into the twenty-first century world of work. Journal of Business and Psychology, 27(2), 123-147. doi:10.1007/s10869-011-9236-3

Barnes, B. J. (2010). The nature of exemplary doctoral advisors' expectations and the ways they may influence doctoral persistence. Journal of College Student Retention, 11(3), 323-343. doi:10.2190/CS.11.3.b

Barnes, B. Y., \& Randall, J. (2012). Doctoral student satisfaction: An examination of disciplinary, enrollment, and institutional differences. Research in Higher Education, 53, 47-75. doi:10.1007/s11162-0119225-4 
Bauer, W. C. (1997). Pursuing the Ph.D.: Importance of structure, goal-setting and advising practices in the completion of the doctoral dissertation. Doctoral dissertation, University of California, Los Angeles. Dissertation Abstracts International, 58(O6A).

Bauer, T. N., \& Green, S. G. (1996). Development of leader-member exchange: A longitudinal test. Academy of Management Journal, 39(6), 1538-1567. doi:10.2307/257068

Biglan, A. (1973). The characteristics of subject matter in different academic areas. Journal of Applied Psychology, 57, 195-203. doi: 10.1037/h0034701

Braxton, J., \& Bayer, A. E. (1999). Faculty misconduct in collegiate teaching. Baltimore, MD: Johns Hopkins University Press.

Brotheridge, C. M., \& Lee, R. T. (2003). Development and validation of the Emotional Labour Scale, Journal of Occupational and Organizational Psychology, 76, 365-379. doi:10.1348/096317903769647229

Clewell, B. C. (1987). Retention of black and Hispanic doctoral students. ETS Research Report Series, 1987, i-89. doi: 10.1002/j.2330-8516.1987.tb00214.x

Cropanzano, R., Howes, J. C., Grandey, A. A., \& Toth, P. (1997). The relationship of organizational politics and support to work behaviors, attitudes, and stress. Journal of Organizational Behavior, 18(2), 159-180. doi: 10.1002/(SICI)1099-1379(199703)18:2<159

Cropanzano, R., Rupp, D. E., \& Byrne, Z. S. (2003). The relationship of emotional exhaustion to work attitudes, job performance, and organizational citizenship behaviors. Journal of Applied Psychology, 88(1), 160-169. doi: 10.1037/0021-9010.88.1.160

Delamont, S., Atkinson, P., \& Parry, O. (2004). Supervising the doctorate: A guide to success. Berkshire, UK: Open University Press.

De Valero, Y. F. (2001). Departmental factors affecting time-to-degree and completion rates of doctoral students at one land-grant research institution. Journal of Higher Education, 72(3), 341-367. doi: $10.2307 / 2649335$

Eisenberger, R., Armeli, S., Rexwinkel, B., Lynch, P. D., \& Rhoades, L. (2001). Reciprocation of perceived organizational support. Journal of Applied Psychology, 86(1), 42-51. doi: 10.1037/00219010.86.1.42

Gardner, S. K. (2007). "I heard it through the grapevine": Doctoral student socialization in chemistry and history. Higher Education, 54, 723-740. doi: 10.1007/s10734-006-9020-x

Gardner, S. K. (2008). Fitting the mold of graduate school: A qualitative study of socialization in doctoral education. Innovative Higher Education, 33(2), 125-138. doi: 10.1007/s10755-008-9068-x

Gardner, S. K. (2009). Student and faculty attributions of attrition in high and low-completing doctoral programs in the United States. Higher Education, 58, 97-112. doi: 10.1007/s10734-008-9184-7

Gardner, S. K. (2010). Contrasting the socialization experiences of doctoral students in high-and lowcompleting departments: a qualitative analysis of disciplinary contexts at one institution. The Journal of Higher Education, 81(1), 61-81. doi: 10.1353/jhe.0.0081

Gardner, S. K., \& Gopaul, B. (2012). The part-time doctoral student experience. International Journal of Doctoral Studies, 7, 63-78. Retrieved from http://ijds.org/Volume7/IJDSv7p063078Gardner352.pdf?origin=publication_detail

Gerstner, C. R., \& Day, D. V. (1997). Meta-analytic review of leader-member exchange theory: Correlates and construct issues. Journal of Applied Psychology, 82(6), 827-844. doi: 10.1037/0021-9010.82.6.827

Golde, C. M. (2001). Questions to ask when thinking about pursuing a Ph.D. Madison: Wisconsin Center for Education Research at the University of Wisconsin-Madison. Retrieved from http://www.phdsurvey.org/advice/advice.htm 
Golde, C. M. (2005). The role of the department and discipline in doctoral student attrition: Lessons from four departments. Journal of Higher Education, 76(6), 669-700. doi: 10.1353/jhe.2005.0039.

Golde, C. M., \& Dore, T. M. (2001). At cross purposes: What the experiences of doctoral students reveal about doctoral education. Philadelphia: Pew Charitable Trusts. Retrieved from http://www.phdsurvey.org

Graen, G. B., \& Scandura, T. A. (1987). Toward a psychology of dyadic organizing. Research in Organizational Behavior, 9, 175-208. Retrieved from http://psycnet.apa.org/index.cfm?fa=search.displayRecord\&UID=1988-15584-001

Green, K. E. (1997). Psychosocial factors affecting dissertation completion. New Directions for Higher Education, 99, 57-64. doi: 10.1002/he.9905

Hair, J. F., Anderson, R. E., Tatham, R. L., \& Black, W. C. (1998). Multivariate data analysis (5th ed.). Englewood Cliffs, NJ: Prentice Hall.

Halbesleben, J. R. (2006). Sources of social support and burnout: a meta-analytic test of the conservation of resources model. Journal of applied Psychology, 91(5), 1134. doi: 10.1037/0021-9010.91.5.1134

Harris, K. J., \& Kacmar, K. M. (2006). Too much of a good thing: the curvilinear effect of leader-member exchange on stress. The Journal of Social Psychology, 146(1), 65-84. doi: 10.3200/SOCP.146.1.65-84

Hawley, P. (2003). Being bright is not enough: The unwritten rules of doctoral study. Springfield, IL: Thomas Books.

Heath, T. (2002). A quantitative analysis of PhD students' views of supervision. Higher Education Research \& Development, 21(1), 41-53. doi: 10.1080/07294360220124648

Hopwood, N. (2010). A sociocultural view of doctoral students' relationships and agency. Studies in Continuing Education, 32(2), 103-117. doi: 10.1080/0158037X.2010.487482

Houkes, I., Janssen, P. M., de Jonge, J., \& Bakker, A. B. (2003). Specific determinants of intrinsic work motivation, emotional exhaustion and turnover intention: A multisample longitudinal study. Journal of Occupational and Organizational Psychology, 76, 427-450. doi: 10.1348/096317903322591578

Hu, L. T., \& Bentler, P. M. (1999). Cutoff criteria for fit indices in covariance structure analysis: Conventional criteria versus new alternatives. Structural Equation Modeling: A Multidisciplinary Journal, 6(1), 1-55. doi: 10.1080/10705519909540118

Jairam, D., \& Kahl, D. H., Jr. (2012). Navigating the doctoral experience: the role of social support in successful degree completion. International Journal of Doctoral Studies, 7, 311-329. Retrieved from http://ijds.org/Volume7/IJDSv7p311-329Jairam0369.pdf

Jazvac-Martek, M., Chen, S., \& McAlpine, L. (2011). Tracking doctoral student experience over time: Cultivating agency in diverse spaces. In L. McAlpine \& C. Amundsen (Eds.), Doctoral education: Research-based strategies for doctoral students, supervisors and administrators (pp. 17-36). The Netherlands: Springer.

Jiranek, V. (2010). Potential predictors of timely completion among dissertation research students at an Australian Faculty of Sciences. International Journal of Doctoral Studies, 5, 1-13. Retrieved from http://ijds.org/Volume5/IJDSv5p001-013Jiranek273.pdf

Jones, W. A. (2011). Variation among academic disciplines: An update on analytical frameworks and research. Journal of the Professoriate, 6(1), 10. Retrieved from http://jotp.icbche.org/2012/6_1_Jones_9_finalBBJ.pdf

Jump, P. (2013, July 26). PhD completion rates, 2013. Times Higher Education. Retrieved from http://www.timeshighereducation.co.ul/news/phd-completion rates-2013/2006020.article

Juniper, B., Walsh, E., Richardson, A., \& Morley, B. (2012). A new approach to evaluating the well-being of PhD research students. Assessment \& Evaluation in Higher Education, 37(5), 563-576. doi:10.1080/02602938.2011.555816 
Kehm, B. M. (2006). Doctoral education in Europe and North America: A comparative analysis. In U. Teichler (Ed.), The formative years of scholars (pp. 67-78). Wenner-Gren International Series, Vol. 83. London: Portland Press.

Kerlin, S. P. (1995). Pursuit of the Ph.D.: "Survival of the fittest," or is it time for a new approach? Education Policy Analysis Archives, 3(16), 1-28. Retrieved from http://epaa.asu.edu/ojs/article/viewFile/659/781

Klomparens, K. L, \& Beck, J. P. (2004). Michigan State University's conflict resolution program: Setting expectations and resolving conflicts. In D. H. Wulff \& A. E. Austin (Eds.). Paths to the professoriate: Strategies for enriching the preparation of future faculty. San Francisco: Jossey-Bass.

Kurtz-Costes, B., Helmke, L. A., \& Ulku-Steiner, B. (2006). Gender and doctoral studies: The perceptions of $\mathrm{PhD}$ students in an American university. Gender \& Education, 18(2), 137-155. doi:10.1080/09540250500380513

Leder, G. C. (1995). Higher degree research supervision: A question of balance. Australian Universities' Review, 2, 5-8. Retrieved from http://files.eric.ed.gov/fulltext/EJ523101.pdf

Lee, A. (2012). Successful research supervision. New York: Routledge.

Lee, R. T., \& Ashforth, B. E. (1996). A meta-analytic examination of the correlates of the three dimensions of job burnout. Journal of Applied Psychology, 81, 123-133. doi: 10.1037/0021-9010.81.2.123

Li, S., \& Seale, C. (2007). Managing criticism in PhD supervision: A qualitative case study. Studies in Higher Education, 32(4), 511-526. doi: 10.1080/03075070701476225

Liden, R. C., \& Maslyn, J. M. (1998). Multidimensionality of leader-member exchange: An empirical assessment through scale development. Journal of Management, 24(1), 43-72. doi:10.1177/014920639802400105

Lovitts, B. E. (2001). Leaving the ivory tower: The causes and consequences of departure from doctoral study. Lanham, MD: Rowman \& Littlefield.

Lovitts, B. E., \& Nelson, C. (2000). The hidden crisis in graduate education: Attrition from PhD programs. Retrieved from http://www.aaup.org/AAUP/pubsres/academe/2000/ND/Feat/lovi.html

Martinuso, M., \& Turkulainen, V. (2011). Personal commitment, support and progress in doctoral studies. Studies in Higher Education, 36(1), 103-120. doi: 10.1080/03075070903469598

Maslach, C., \& Jackson, S. E. (1981). The measurement of experienced burnout. Journal of Organizational Behavior, 2(2), 99-113. doi: 10.1002/job.4030020205

Moore, J. E. (2000). Why is this happening? A causal attribution approach to work exhaustion consequences. Academy of Management Review, 25(2), 335-349. doi: 10.5465/AMR.2000.3312920

Muthén, L. K., \& Muthén, B. O. (2012). Mplus: Statistical analysis with latent variables: User's guide (7th ed.). Los Angeles, CA: Muthén \& Muthén.

Offsetin, E. H., Larson, M. B., McNeill, A. L., \& Mwale, H. M. (2004). Are we doing enough for today's graudate student? International Journal of Educational Management, 18(7), 396-407. doi:10.1108/09513540410563103

Onwuegbuzie, A. J., \& Wao, H. O. (2011). A mixed research investigation of factors related to time to the doctorate in education. International Journal of Doctoral Studies, 6, 115-134. Retrieved from http://ijds.org/Volume6/IJDSv6p115-134Wao320.pdf

Podsakoff, P. M., MacKenzie, S. B., Lee, J. Y., \& Podsakoff, N. P. (2003). Common method biases in behavioral research: A critical review of the literature and recommended remedies. Journal of Applied Psychology, 88(5), 879-903. doi: 10.1037/0021-9010.88.5.879

Picciano, J., Rudd, E., Morrison, E., \& Nerad, M. (2008). Does time-to-degree matter? CIRGE spotlight on doctoral education \#3. Seattle, WA: Center for Innovation and Research in Graduate Education. Retrieved from http://www.cirge.washington.edu 
Preacher, K. J., \& Hayes, A. F. (2008). Asymptotic and resampling strategies for assessing and comparing indirect effects in multiple mediator models. Behavior Research Methods, 40, 879-891. doi:10.3758/BRM.40.3.879

Proost, K., van Ruysseveldt, J., \& van Dijke, M. (2012). Coping with unmet expectations: Learning opportunities as a buffer against emotional exhaustion and turnover intentions. European Journal of Work and Organizational Psychology, 21(1), 7-27. doi: 10.1080/1359432X.2010.526304

Pyhältö, K., Toom, A., Stubb, J., \& Lonka, K. (2012). Challenges of becoming a scholar: A study of experienced problems and well-being of doctoral students. ISRN Education, 12. doi:org/10.5402/2012/934941

Rhoades, L., \& Eisenberger, R. (2002). Perceived organizational support: A review of the literature. Journal of Applied Psychology, 87(4), 698-714. doi: 10.1037/0021-9010.87.4.698

Rigg, J., Day, J., \& Adler, H. (2013). Emotional exhaustion in graduate students: The role of engagement, self-efficacy, and social support. Journal of Educational and Developmental Pyschology, 3(2), 138152. doi: 10.5539/jedp.v3np138

Rodriguez, N. M., \& Ryave, A. I. (2002). Systematic self-observation: A method for researching the hidden and elusive features of everyday social life. London: Sage.

Rousseau, D. M. (1996). Changing the deal while keeping the people. Academy of Management Perspectives, 10(1), 50-59. doi: 10.5465/AME.1996.9603293198

Sambrook, S., Stewart, J., \& Roberts, C. (2008). Doctoral supervision ... a view from above, below and the middle! Journal of Further and Higher Education, 32(1), 71-84. doi: 10.1080/03098770701781473

Shannon, A. G. (1995). Research degree supervision: 'more mentor than master.' Australian Universities' Review, 2, 12-15. Retrieved from http://citeseerx.ist.psu.edu/viewdoc/download?doi=10.1.1.188.9509\&rep=rep1\&type=pdf\#page=13

Shelton, E. (2003). Faculty support and student retention. Journal of Nursing Education, 42(2), 68-76. Retrieved from http://www.healio.com/journals/jne

Shore, L. M. F., \& Martin, H. J. (1989). Job satisfaction and organizational commitment in relation to work performance and turnover intentions. Human Relations, 42(7), 625-638. doi:10.1177/001872678904200705

Sonnentag, S., Kuttler, I., \& Fritz, C. (2010). Job stressors, emotional exhaustion, and need for recovery: A multi-source study on the benefits of psychological detachment. Journal of Vocational Behavior, 76(3), 355-365. doi: 10.1016/j.jvb.2009.06.005

Sparrowe, R. T., \& Liden, R. C. (1997). Process and structure in leader-member exchange. Academy of Management Review, 22(2), 522-552. doi: 10.5465/AMR.1997.9707154068

Spaulding, L. S., \& Rockinson-Szapkiw, A. J. (2012). Hearing their voices: factors doctoral candidates attribute to their persistence. International Journal of Doctoral Studies, 7, 199-219. Retrieved from http://ijds.org/Volume7/IJDSv7p199-219Spaulding334.pdf

Spector, P. E., \& Brannick, M. T. (2011). Methodological urban legends: The misuse of statistical control variables. Organizational Research Methods, 14(2), 287-305. doi: 10.1177/1094428110369842

Stallone, M. N. (2004). Factors associated with student attrition and retention in an educational leadership doctoral program. Journal of College Teaching \& Learning, 1(6), 17-24. Retrieved from http://www.cluteonline.com/journals/index.php/TLC/article/view/1952/1931

Stoecker, J. L. (1993). The Biglan classification revisited. Research in Higher Education, 34(4), 451-464. doi: 10.1007/BF00991854

Stubb, J., Pyhältö, K., \& Lonka K. (2011). Balancing between inspiration and exhaustion: PhD students' experienced socio-psychological well-being. Studies in Continuing Education, 33(1), 33-50. doi:10.1080/0158037X.2010.515572 
Twale, D. J., \& DeLuca, B. M. (2008). Faculty incivility: The rise of the academic bully culture and what to do about it. San Francisco, CA: Jossey-Bass.

Ugrin, J. C., Odom, M. D., \& Pearson, J. M. (2008). Exploring the importance of mentoring for new scholars: A social exchange perspective. Journal of Information Systems Education, 19(3), 343-350. Retrieved from http://eric.ed.gov/?id=EJ831393

Van Dyne, L., Kamdar, D., \& Joireman, J. (2008). In-role perceptions buffer the negative impact of low LMX on helping and enhance the positive impact of high LMX on voice. Journal of Applied Psychology, 93(6), 1195. doi: 10.1037/0021-9010.93.6.1195

Wade-Benzoni, K. A., Rousseau, D. M., \& Li, M. (2011). Managing relationships across generations of academics: Psychological contracts in faculty-doctoral student collaborations. International Journal of Conflict Management, 17(1), 4-33. doi: 10.1108/10444060610734154

Weidman, J. C., \& Stein, E. L. (2003). Socialization of doctoral students to academic norms. Research in Higher Education, 44(6), 641-656. doi: 10.1023/A:1026123508335

West, I. J., Gokalp, G., Vallejo, A. E., Fischer, L., \& Gupton, J. (2011). Exploring effective support practices for doctoral students' degree completion. College Student Journal, 45(2), 310-323. Retrieved from http://www.academia.edu/736556/

Williams, L. J., Cote, J. A., \& Buckley, M. R. (1989). Lack of method variance in self-reported affect and perceptions at work: reality or artifact? Journal of Applied Psychology, 74(3), 462. doi: 10.1037/00219010.74.3.462

Wisker, G. (2012). The good supervisor. New York: Palgrave Macmillan.

Wright, T. A., \& Cropanzano, R. (1998). Emotional exhaustion as a predictor of job performance and voluntary turnover. Journal of Applied Psychology, 83(3), 486-493. doi: 10.1037/0021-9010.83.3.486

$\mathrm{Xu}, \mathrm{Y}$. J. (2008). Faculty turnover: Discipline-specific attention is warranted. Research in Higher Education, 49(1), 40-61. Doi: 10.1007/s11162-007-9062-7.

Zhao, C. M., Golde, C. M., \& McCormick, A. C. (2007). More than a signature: How advisor choice and advisor behavior affect doctoral student satisfaction. Journal of Further and Higher Education, 31(3), 263-281. doi: 10.1080/03098770701424983

Zhou, Y., \& Volkwein, J. F. (2004). Examining the influences on faculty departure intentions: A comparison of tenured versus nontenured faculty at research universities using NSOPF-99. Research in Higher Education, 45(2), 139-176. doi: 10.1023/B:RIHE.0000015693.38603.4c

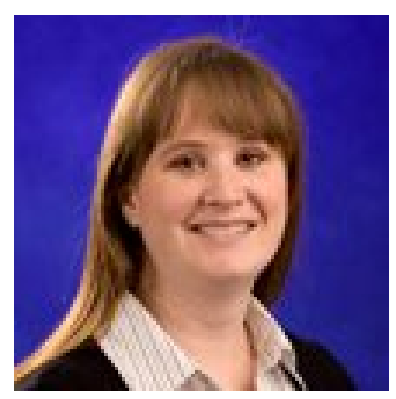

\section{Biographies}

Karen Hunter completed her $\mathrm{PhD}$ at the University of Alberta in 2010. As an organizational behavior researcher, her research interests primarily focus on how individuals' perceptions of their work environment and relationships influence their work attitudes, behavior, performance, and self-presentation. In addition to her research on doctoral student well-being, she also conducts research on voice and silence, facades of conformity, and service quality in assisted living facilities. 


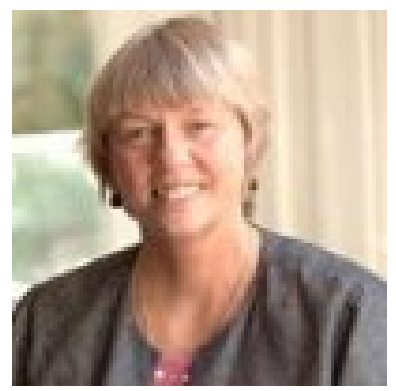

Kay Devine is a Professor and Program Director of the Doctorate in Business Administration with Athabasca University, Canada's Open University. Her current research focuses on the experience of doctoral students, including best practices in doctoral student supervision. 